DOI: $10.4274 /$ tjps.53215

\title{
Flavonoid Glycosides From Heracleum pastinaca Fenzl.
}

Perihan Gürbüz

Department Of Pharmacognosy, Erciyes University Faculty Of Pharmacy, Kayseri, Turkey

\begin{abstract}
INTRODUCTION: The objective is the study to isolate and characterize the secondary metabolites of Heracleum pastinaca which has not been previously investigated.
\end{abstract}

METHODS: Conventional chromatographic procedures were carried out for isolation of the compounds. The structures of the compounds were elucidated by extensive 1D and 2D NMR spectroscopic analysis in combination with MS experiments and comparing with relevant litearature data.

RESULTS: The first phytochemical investigation on the whole parts of Heracleum pastinaca Fenzl. led to the isolation and identification of seven known flavonoid glycosides; isoquercetin (1), rutin (2), afzelin (3), astragalin (4), isorhamnetin 3-O-glucoside (5), nicotiflorine (6) and narcissoside (7).

DISCUSSION AND CONCLUSION: This is the first report on the isolation of these flavonoid glycosides from $\mathrm{H}$. pastinaca and compounds 3, 5, 6 and 7 from genus Heracleum.

Keywords: Heracleum, Apiaceae, isorhamnetin, flavonoid glycosides, chemotaxonomy

\section{INTRODUCTION}

The genus Heracleum which is known as "hogweed," is one of the largest genera of Apiaceae containing more than 120 species widely distributed in Central Europe and Asia as well as 17 species with $41 \%$ endemism in flora of Turkey. ${ }^{1-2}$

Heracleum species have been traditionally used as spice and food additive as well as in the treatment of inflammation, flatulence, stomachache, epilepsy and psoriasis. They also act as carminative, antiseptic, antimicrobial, analgesic and anticonvulsant agents. ${ }^{3}$ Some Heracleum species are used traditionally for different purposes i.e. H. crenatifolium as vegetable and condiment ${ }^{4}$; H. trachyloma against asthma and bronchitis ${ }^{5}$; H. spondylium L. subsp. ternatum as galactagogue ${ }^{6} ; H$. persicum and $H$. platytaenium for gastritis, epilepsy and as sedative ${ }^{7}$ in Turkey. 
There are plenty of phytochemical studies on Heracleum species mainly focused on furanocoumarins ${ }^{8-9}$ and furanocoumarin glycosides 10-11 together with alkaloids ${ }^{12}$, polyacetylenes ${ }^{13}$ and flavonoids. ${ }^{14-16}$ Essential oil compounds of the genus were also studied. ${ }^{17-19}$ Although the phytochemical studies and bioactivity studies are mostly conducted with the coumarin compounds of the genus, we would like to examine the flavonoid content of $H$. pastinaca Fenzl. (Figure 1) which is a rare endemic tiny plant, mainly distributed in the inner and the southwest region of Anatolia. ${ }^{20}$

Conventional chromatographic purification procedures were carried out to isolate the compounds of the H. pastinaca. The structures of the compounds were elucidated by extensive 1D and 2D NMR and ESI-MS experiments confirmed by the relevant literature data. Chemotaxonomic significance of the compounds was discussed.

\section{EXPERIMENTAL}

General

NMR (400 MHz for ${ }^{1} \mathrm{H}$ NMR, $100 \mathrm{MHz}$ for ${ }^{13} \mathrm{C} \mathrm{NMR}$, both use TMS as internal standard) were measured on a Bruker AM 400 spectrometer and MS spectra on a LC/MS Shimadzu 8040 instrument. Kieselgel 60 (Merck, 0.063-0.200 mm) was used for open column chromatography (CC). Sephadex LH-20 (SP LH-20) (General Electrics Healthcare) was used for Gel Permeation Chromatography (GPC). LiChroprep $\mathrm{C}_{18}$ (Merck, 40-63 $\mu \mathrm{m}$ ) was used for Medium Pressure Liquid Chromatography (MPLC) (Buchi Pump Module: C-601, UVPhotometer: C-640, control Unit: C-620, Fr. Collector: C-660). TLC analyses were carried out on pre-coated Kieselgel $60 \mathrm{~F}_{25}$ aluminum plates (Merck). Compounds were detected by UV fluorescence and spraying $1 \%$ vanillin $/ \mathrm{H}_{2} \mathrm{SO}_{4}$, followed by heating at $100{ }^{\circ} \mathrm{C}$ for $1-2 \mathrm{~min}$.

\section{Plant material}

Whole parts (aerial parts \& roots) of $H$. pastinaca were collected from Maden- Kiz1ltepe region (Niğde-Uhukışla), at about $2600 \mathrm{~m}$ altitude of calcareous rock clefts on August 2017. A voucher specimen was deposited at the Herbarium of Hacettepe University, Faculty of Pharmacy under the code HUEF-17015.

\section{Extraction and isolation}

The dried and powdered whole parts of $H$. pastinaca $(90 \mathrm{~g})$ was extracted with $\mathrm{MeOH}(500$ $\mathrm{mL} \times 4$ ) at $37{ }^{\circ} \mathrm{C}$. After the evaporation of the solvent (yield 18\%), the crude $\mathrm{MeOH}$ extract $(17 \mathrm{~g})$ was first dissolved in water than partitioned between $n$-hexane and $n$-BuOH respectively. $\mathrm{n}-\mathrm{BuOH}(4.5 \mathrm{~g})$ extract was first submitted to column chromatography on 
Sephadex LH-20 (2,5 x $60 \mathrm{~cm})$ and eluted with MeOH. Four main fractions (Fr. 1 (1.7 g); Fr. 2 (2.2 g), Fr. 3 (332.6 mg), Fr. 4 (130 mg) were obtained. Fr. 3 (332.6 mg) was submitted to reverse phase column $(1.5 \mathrm{~cm} \times 15 \mathrm{~cm})$ and eluted with gradient $\mathrm{H}_{2} \mathrm{O}: \mathrm{MeOH}$ solvent system $(10 \% \rightarrow 50 \% ; 10 \mathrm{~mL} / \mathrm{min} ; 4-5 \mathrm{mbar})$ with the MPLC system coupled with a fraction collector to give four sub fractions (Fr.3 a-d).

Fr. 3d gave compound 3 (4 mg). Further purification of Fr. 3a $(116 \mathrm{mg})$ with reverse phase column $(1.5 \mathrm{~cm} \times 15 \mathrm{~cm})$ and eluted with gradient $\mathrm{H}_{2} \mathrm{O}: \mathrm{MeOH}$ solvent system $(20 \% \rightarrow 30 \%$; $10 \mathrm{~mL} / \mathrm{min}$; 4-5 mbar) yielded two sub fractions. These two fractions were submitted to TLC plate $(20 \times 20 \mathrm{~cm})$ separately and eluted with $70: 30: 3\left(\mathrm{CHCl}_{3}: \mathrm{MeOH}: \mathrm{H} 2 \mathrm{O}\right)$ to yield compounds 1 (22 $\mathrm{mg}$ ) and compound $2(32 \mathrm{mg})$ respectively. Fr. 3c (63 mg) was submitted to two different TLC plates $(20 \times 20 \mathrm{~cm})$ and eluted with 70:30:3 (CHCl3: MeOH: H2O). After elution, the bands that belong to the compounds were detected under $\mathrm{UV}_{254}$ light and scraped to obtain compounds 4 and 5 (24 mg) and compounds 6 and 7 (16 $\mathrm{mg}$ ) respectively as mixtures.

\section{Structure elucidation}

The structures of the compounds (Figure 2) were elucidated by 1D and 2D NMR experiments. The positions of the sugar units are confirmed by 2D HMBC experiments. Together with ESIMS data and comparison with relevant literature the compounds are elucidated as follows; isoquercetin (1) ${ }^{21}$, rutin (2) ${ }^{21-22}$, afzelin (3) ${ }^{23}$, astragalin (4) ${ }^{21,24}$, isorhamnetin $3-O-\beta$ glucopyranoside (5) ${ }^{25}$, kaempferol 3-O-rutinoside (6) ${ }^{21-22}$ and isorhamnetin 3-O-rutinoside (7). ${ }^{22}$

Quercetin 3-O- $\beta$-glucopyranoside (Isoquercetin) (1)

Yellow powder; Negative ESI/MS m/z: $463[\mathrm{M}-\mathrm{H}]]^{-} ;{ }^{1} \mathrm{H}$ NMR (400 MHz, MeOH- $\left.d_{4}\right) \delta 7.72$ (d, $\left.J=2.1 \mathrm{~Hz}, 1 \mathrm{H}, \mathrm{H}-2^{\prime}\right), 7.58\left(\mathrm{dd}, J=8.5,2.1 \mathrm{~Hz}, 1 \mathrm{H}, \mathrm{H}-6^{\prime}\right), 6.86$ (d, J=8.5 Hz, 1H, H-5'), 6.24 (d, $J=2.0 \mathrm{~Hz}, 1 \mathrm{H}, \mathrm{H}-8), 6.08$ (d, $J=2.0 \mathrm{~Hz}, 1 \mathrm{H}, \mathrm{H}-6), 5.11$ (d, J=7.6 Hz, 1H, H-1"), 3.71 (dd, $\left.J=11.8,2.3 \mathrm{~Hz}, 1 \mathrm{H}, \mathrm{H}-6 \mathrm{a}^{\prime \prime}\right), 3.59\left(\mathrm{dd}, J=12.5,4.6 \mathrm{~Hz}, 1 \mathrm{H}, \mathrm{H}-6 \mathrm{~b}^{\prime \prime}\right), 3.56-3.17$ (m, 4H, remaining sugar signals).

Quercetin 3-O- $\alpha$-rhamnopyranosyl $(1 \rightarrow 6)-\beta$-glucopyranoside (Rutin) (2)

Yellow powder; Negative ESI/MS m/z: 609 [M-H]; ; ${ }^{1} \mathrm{H}$ NMR (400 MHz, MeOH-d4) $\delta 7.68$ (brs, 1H, H-2'), 7.64 (brd, J=8.0 Hz, 1H, H-6'), 6.87 (d, J=8.2 Hz, 1H, H-5'), 6.30 (brs, 1H, H- 
8), 6.13 (brs, 1H, H-6), 5.03 (d, J=7.6 Hz, 1H, H-1"), 4.53 (brs, 1H, H-1'"'), 3.81 (brd, $J=10.5$ $\left.\mathrm{Hz}, 1 \mathrm{H}, \mathrm{H}-6 \mathrm{a}^{\prime \prime}\right), 3.70-3.20$ (m, 9H, remaining sugar signals), 1.15 (d, J=6.2 Hz, 3H).

Kaempferol 3-O- $\alpha$-rhamnopyranoside (Afzelin) (3)

Yellow powder; Negative ESI/MS m/z: $431[\mathrm{M}-\mathrm{H}]^{-} ;{ }^{1} \mathrm{H}$ NMR $\left(400 \mathrm{MHz}, \mathrm{MeOH}-d_{4}\right) \delta 7.78$ (d, $\left.J=8.9 \mathrm{~Hz}, 2 \mathrm{H}, \mathrm{H}-2^{\prime}, 6^{\prime}\right), 6.95$ (d, $\left.J=8.8 \mathrm{~Hz}, 2 \mathrm{H}, \mathrm{H}-3^{\prime}, 5^{\prime}\right), 6.39$ (d, $\left.J=2.1 \mathrm{~Hz}, 1 \mathrm{H}, \mathrm{H}-8\right)$, (d, $J=2.1 \mathrm{~Hz}, 1 \mathrm{H}, \mathrm{H}-6), 5.38$ (d, $\left.J=1.6 \mathrm{~Hz}, 1 \mathrm{H}, \mathrm{H}-1^{\prime \prime}\right), 4.23$ (dd, $\left.J=3.3,1.6 \mathrm{~Hz}, 1 \mathrm{H}, \mathrm{H}-2^{\prime \prime}\right), 3.76$ -3.68 (m, 1H, H-3"), $3.53-3.40$ (m, 2H, H-4", 5"), 0.93 (d, J=5.7 Hz, 3H, H-6").

Kaempferol 3-O- $\beta$-glucopyranoside (Astragalin) (4)

Yellow powder; Negative ESI/MS m/z: 447 [M-H] ; ${ }^{1} \mathrm{H}$ NMR (400 MHz, MeOH-d4) $\delta 8.04$ (d, $\left.J=8.8 \mathrm{~Hz}, 2 \mathrm{H}, \mathrm{H}-2^{\prime}, 6^{\prime}\right), 6.89$ (d, $\left.J=8.2 \mathrm{~Hz}, 2 \mathrm{H}, \mathrm{H}-3^{\prime}, 5^{\prime}\right), 6.24$ (d, J=1.9 Hz, 1H, H-8), 6.09 (d, $J=1.9 \mathrm{~Hz}, 1 \mathrm{H}, \mathrm{H}-6$ ), 5.27 (d, $\left.J=7.3 \mathrm{~Hz}, 1 \mathrm{H}, \mathrm{H}-1^{\prime \prime}\right), 3.76-3.57$ (m, 2H, H-6"), 3.56 $3.16(\mathrm{~m}, 4 \mathrm{H}$, remaining sugar signals).

Isorhamnetin 3-O- $\beta$-glucopyranoside (5)

Yellow powder; Negative ESI/MS m/z: 477 [M-H] ; ${ }^{1} \mathrm{H}$ NMR (400 MHz, MeOH-d4) $\delta 7.91$ (d, $\left.J=1.9 \mathrm{~Hz}, 1 \mathrm{H}, \mathrm{H}-2^{\prime}\right), 7.59$ (dd, $\left.J=8.5,1.9 \mathrm{~Hz}, 1 \mathrm{H}, \mathrm{H}-6^{\prime}\right), 6.89$ (d, $\left.J=8.5 \mathrm{~Hz}, 1 \mathrm{H}, \mathrm{H}-5^{\prime}\right), 6.24$ (d, J=1.9 Hz, 1H, H-8), 6.09 (d, J=1.9 Hz, 1H, H-6), 5.10 (d, J=7.4 Hz, 1H, H-1"), 3.94 (s, $\left.3 \mathrm{H}, \mathrm{OC}_{3} 3\right), 3.76-3.57$ (m, 2H, H-6"), 3.56-3.16 (m, 4H, remaining sugar signals).

Kaempferol 3-O-rutinoside (Nicotiflorin) (6)

Yellow powder; Negative ESI/MS m/z: $593[\mathrm{M}-\mathrm{H}]-{ }^{1} \mathrm{H}$ NMR $\left(400 \mathrm{MHz}, \mathrm{MeOH}-d_{4}\right) \delta 8.06$ (d, $J=8.8 \mathrm{~Hz}, 2 \mathrm{H}, \mathrm{H}-2^{\prime}, 6^{\prime}$ ), 6.89 (d, J=8.0 Hz, 2H, H-3', 5'), 6.28 (brs, 1H, H-8), 6.12 (d, J $=1.8 \mathrm{~Hz}, 1 \mathrm{H}, \mathrm{H}-6), 5.14$ (d, J=7.3 Hz, 1H, H-1"'), 4.51 (brs, 1H, H-1'"'), 3.86-3.62 (m, 2H, H$\left.6^{\prime \prime}\right), 3.61-3.22$ (m, 8H, remaining sugar signals), 1.15 (d, $\left.6.2 \mathrm{~Hz}, 3 \mathrm{H}, \mathrm{H}-6^{\prime \prime \prime}\right)$.

Isorhamnetin 3-O-rutinoside (Narcissoside) (7)

Yellow powder; Negative ESI/MS m/z: 623[M-H] ; ${ }^{1} \mathrm{H}$ NMR $\left(400 \mathrm{MHz}, \mathrm{MeOH}-d_{4}\right) 7.95$ (d, $\left.J=1.8 \mathrm{~Hz}, 1 \mathrm{H}, \mathrm{H}-2^{\prime}\right), 7.62\left(\mathrm{dd}, J=8.5,1.8 \mathrm{~Hz}, 1 \mathrm{H}, \mathrm{H}-6^{\prime}\right), 6.89$ (d, $\left.J=8.0 \mathrm{~Hz}, 1 \mathrm{H}, \mathrm{H}-5^{\prime}\right), 6.28$ (brs, 1H, H-8), 6.12 (d, J=1.8 Hz, 1H, H-6), 5.02 (d, J=7.3 Hz, 1H, H-1"), 4.52 (brs, 1H, H$\left.1^{\prime \prime \prime}\right), 3.95\left(\mathrm{~s}, 3 \mathrm{H}, \mathrm{OC}_{3}\right)$ 3.86-3.62 (m, 2H, H-6"), 3.61-3.22 (m, 8H, remaining sugar signals), 1.12 (d, $\left.6.2 \mathrm{~Hz}, 3 \mathrm{H}, \mathrm{H}-6^{\prime \prime \prime}\right)$. 


\section{RESULTS AND DISCUSSION}

The present work reports for the first time the characterization of seven flavonoid glycosides 1-7 from the whole parts of $H$. pastinaca. To best of our knowledge, this is the first report of compounds 3, 5, 6 and 7 from the genus Heracleum while others were reported from different Heracleum species. i.e. isoquercetin (1) from H. napalense ${ }^{26}$ and H. mollendorfii ${ }^{15}$; astragalin from $H$. mollendorfii ${ }^{15}$ and rutin from $H$. sphondylium ${ }^{27-28}$ before. The presence of flavonoids in higher plants has been associated with various environmental conditions such as; high-light/UV-stress, cold stress, nutritional deficiencies and pathogen protection etc. ${ }^{29-31}$ The habitat of the samples were about $2600 \mathrm{~m}$ altitudes where the plants were exposed to a high UV radiation. This fact should effect the production of different type and quantities of flavonoids of the plant. The phytochemical investigation of the Heracleum species are mostly focused on the linear and angular type furanocoumarins and different biological activities of the genus such as, insecticidal, antibacterial, antiviral and antifungal were may be attributed to the these coumarin type compounds. ${ }^{3}$ There are limited phytochemical studies about the isolation of the flavonoids from Heracleum species. Few flavonoids i.e. kaempferol, quercetin, isorhamnetin ${ }^{16}$ rutin ${ }^{28}$, astragalin ${ }^{15}$, flavantaside and epirutin ${ }^{32}$ were reported from different Heracleum species. In this study, the isolated and elucidated flavonols are mainly kaempferol, quercetin and isorhamnetin glycosides. Flavonoids posseses many important biological activities such as antimicrobial ${ }^{33}$, antioxidant ${ }^{34}$, antiviral ${ }^{35}$ etc. The presence of those valuable flavonoids in Heracleum species definitely enriches the chemical diversity and provides evidence for the chemotaxonomic studies of Heracleum species and the family Apiaceae as well.

\section{CONCLUSION}

The first phytochemical study of Heracleum pastinaca led to the isolation and structure identification of seven flavonoid glycosides. The structure of isolated compounds were elucidated by $1 \mathrm{D}$ and 2D NMR analyses, together with ESI-MS data and comparison with relevant literature data; isoquercetin (1) ${ }^{21}$, rutin (2) ${ }^{21-22}$, afzelin (3) ${ }^{23}$, astragalin (4) ${ }^{21,24}$, isorhamnetin 3-O- $\beta$-glucopyranoside (5) ${ }^{25}$, nicotiflorin (6) ${ }^{21-22}$ and narcissoside (7). ${ }^{22}$ Notably this is the first report of these flavonol glycosides from $H$. pastinaca and compounds 3, 5, 6 and 7 from the genus Heracleum. In conclusion, when considering the relationship between the bioactivities and the chemistry of Heracleum species; it should be a possible fact that; flavonoids can also play an important role to contribute the bioactivity and traditional uses of the Heracleum species. 


\section{ACKNOWLEDGEMENTS}

The author is indebted to Dr. Şengül Dilem Doğan (Erciyes University) for helping structure elucidation and Dr. Ahmet Savran for identification of the plant material and for providing the high-resolution photo of the plant.

Conflict of Interest: No conflict of interest was declared by the authors. 


\section{REFERENCES}

1. The Plant List (2013). Version 1.1. Published on the Internet; http://www.theplantlist.org/. (accessed 1st January).

2. http://www.bizimbitkiler.org/Heracleum. (accessed 1st January).

3. Bahadori MB, Dinparast L, Zengin G. The genus Heracleum: a comprehensive review on its phytochemistry, pharmacology, and ethnobotanical values as a useful herb. Compr Rev Food Sci Food Saf. 2016;15:1018-1039.

4. Özgökçe F, Özçelik H. Ethnobotanical aspects of some taxa in East Anatolia, Turkey. Econ Bot. 2004;58:697.

5. Polat R, Cakilcioglu U, Satıl F. Traditional uses of medicinal plants in Solhan (BingölTurkey). J Ethnopharmacol. 2013;148:951-963.

6. Kültür Ş. Medicinal plants used in Kırklareli province (Turkey). J Ethnopharmacol. 2007;111:341-364.

7. Yıldırım B, Terzioglu Ö, Özgökçe F, Türközü D. Ethnobotanical and pharmacological uses of some plants in the districts of Karpuzalan and Adigüzel (Van-Turkey). J Anim Vet Adv. 2008;7:873-878.

8. Razdan TK, Kachroo V, Harkar S, Koul GL. Furanocoumarins from Heracleum canescens. Phytochemistry. 1982;21:923-927.

9. Steck W. Leaf furanocoumarins of Heracleum lanatum. Phytochemistry. 1970;9:11451146.

10. Fischer FC, Jasperse $\mathrm{PH}$, Karlsen J, Svendsen AB. Ein neues furanocumaringlykosid aus Heracleum mantegazzianum. Phytochemistry. 1974;13:2334-2335.

11. Mi J, Peng Y, Zhang H, Wang X, Huo Y, Wang Z, Gao Y, Zhang H. A new benzofuran derivative glycoside and a new coumarin glycoside from roots of Heracleum dissectum Ledeb. Med Chem Res. 2017;1-6.

12. Gupta BD, Banerjee SK, Handa KL. Alkaloids and coumarins of Heracleum wallichii. Phytochemistry. 1976;15:576.

13. Nakano $Y$, Matsunaga $H$, Saita $T$, MORI $M$, KATANO $M$, OKABE $H$. Antiproliferative Constituents in Umbelliferae Plants II.: Screening for Polyacetylenes in Some Umbelliferae Plants, and Isolation of Panaxynol and Falcarindiol from the Root of Heracleum moellendorffii. Biol Pharm Bull. 1998;21:257-261.

14. Ghodsi B. Flavonoids of three Heracleum species: H. persicum L., H. sphondylium L. and H. montanum Schl. Bull Trav Soc Pharm Lyon. 1976;20:3-8. 
15. Park H-J, Nugroho A, Jung B-R, Won Y-H, Jung Y-J, Kim W-B, Choi J-S. Isolation and Quantitative Analysis of Flavonoids with Peroxynitritescavenging Effect from the Young Leaves of Heracleum moellendorffii. Korean J Plant Resour. 2010;23:393-398.

16. Siwon J, Karlsen J. The isolation and identification of flavonoid aglycones from Heracleum mantegazzianum Somm. et Lev. Medd Nor Farm Selsk. 1976;38:11-12.

17. Skalicka-Woźniak K, Grzegorczyk A, Świątek Ł, Walasek M, Widelski J, Rajtar B, Polz-Dacewicz M, Malm A, Elansary HO. Biological activity and safety profile of the essential oil from fruits of Heracleum mantegazzianum Sommier \& Levier (Apiaceae). Food Chem Toxicol. 2017;109:820-826.

18. Firuzi O, Asadollahi M, Gholami M, Javidnia K. Composition and biological activities of essential oils from four Heracleum species. Food Chem. 2010;122:117-122.

19. Iscan G, Ozek T, Ozek G, Duran A, Baser K. Essential oils of three species of Heracleum. Anticandidal activity. Chem Nat Comp. 2004;40:544-547.

20. Babaç MT. Possibility of an information system on plants of South-West Asia with particular reference to the Turkish plants data service (TUBIVES). Turk J Botany. 2004;28:119-127.

21. Han J-T, Bang M-H, Chun O-K, Kim D-O, Lee C-Y, Baek N-I. Flavonol glycosides from the aerial parts of Aceriphyllum rossii and their antioxidant activities. Arch Pharm Res. 2004;27:390-395.

22. Chaurasia N, Wichtl M. Flayonolglykoside aus Urtica dioica 1, 2. Planta Med. $1987 ; 53: 432-434$.

23. Lee SY, So Y-J, Shin MS, Cho JY, Lee J. Antibacterial effects of afzelin isolated from Cornus macrophylla on Pseudomonas aeruginosa, a leading cause of illness in immunocompromised individuals. Molecules. 2014;19:3173-3180.

24. Wei Y, Xie Q, Fisher D, Sutherland IA. Separation of patuletin-3-O-glucoside, astragalin, quercetin, kaempferol and isorhamnetin from Flaveria bidentis (L.) Kuntze by elution-pump-out high-performance counter-current chromatography. J Chromatog A. $2011 ; 1218: 6206-6211$.

25. Lee YS, Lee HS, Shin KH, Kim B-K, Lee S. Constituents of the halophyte Salicornia herbacea. Arch Pharm Res. 2004;27:1034-1036.

26. Dash S, Nath LK, Bhise S. Antioxidant and antimicrobial activities of Heracleum nepalense D Don root. Trop J Pharm Res. 2005;4:341-347. 
27. Benedec D, Hanganu D, Filip L, Oniga I, Tiperciuc B, Olah N-K, Gheldiu A-M, Raita O, Vlase L. Chemical, antioxidant and antibacterial studies of Romanian Heracleum sphondylıum. Farmacia. 2017;65:252-256.

28. Harborne J, Williams CA. Flavonoid patterns in the fruits of the Umbelliferae. Phytochemistry. 1972;11:1741-1750.

29. Dixon RA, Paiva NL. Stress-induced phenylpropanoid metabolism. Plant Cell. $1995 ; 7: 1085$.

30. Kusano M, Tohge T, Fukushima A, Kobayashi M, Hayashi N, Otsuki H, Kondou Y,

Goto H, Kawashima M, Matsuda F. Metabolomics reveals comprehensive reprogramming involving two independent metabolic responses of Arabidopsis to UV-B light. Plant J. 2011;67:354-369.

31. Roberts MR, Paul ND. Seduced by the dark side: integrating molecular and ecological perspectives on the influence of light on plant defence against pests and pathogens. New Phytologist. 2006;170:677-699.

32. Komissarenko N, Satsyperova I. Flavonoids and coumarins of leaves of Heracleum antasiaticum Manden. Rastit Resur. 1974.

33. Cushnie TT, Lamb AJ. Antimicrobial activity of flavonoids. Int J Antimicrob Agents. 2005;26:343-356.

34. Burda S, Oleszek W. Antioxidant and antiradical activities of flavonoids. J Agr Food Chem. 2001;49:2774-2779.

35. Kaul TN, Middleton E, Ogra PL. Antiviral effect of flavonoids on human viruses. J Med Vir. 1985;15:71-79. 


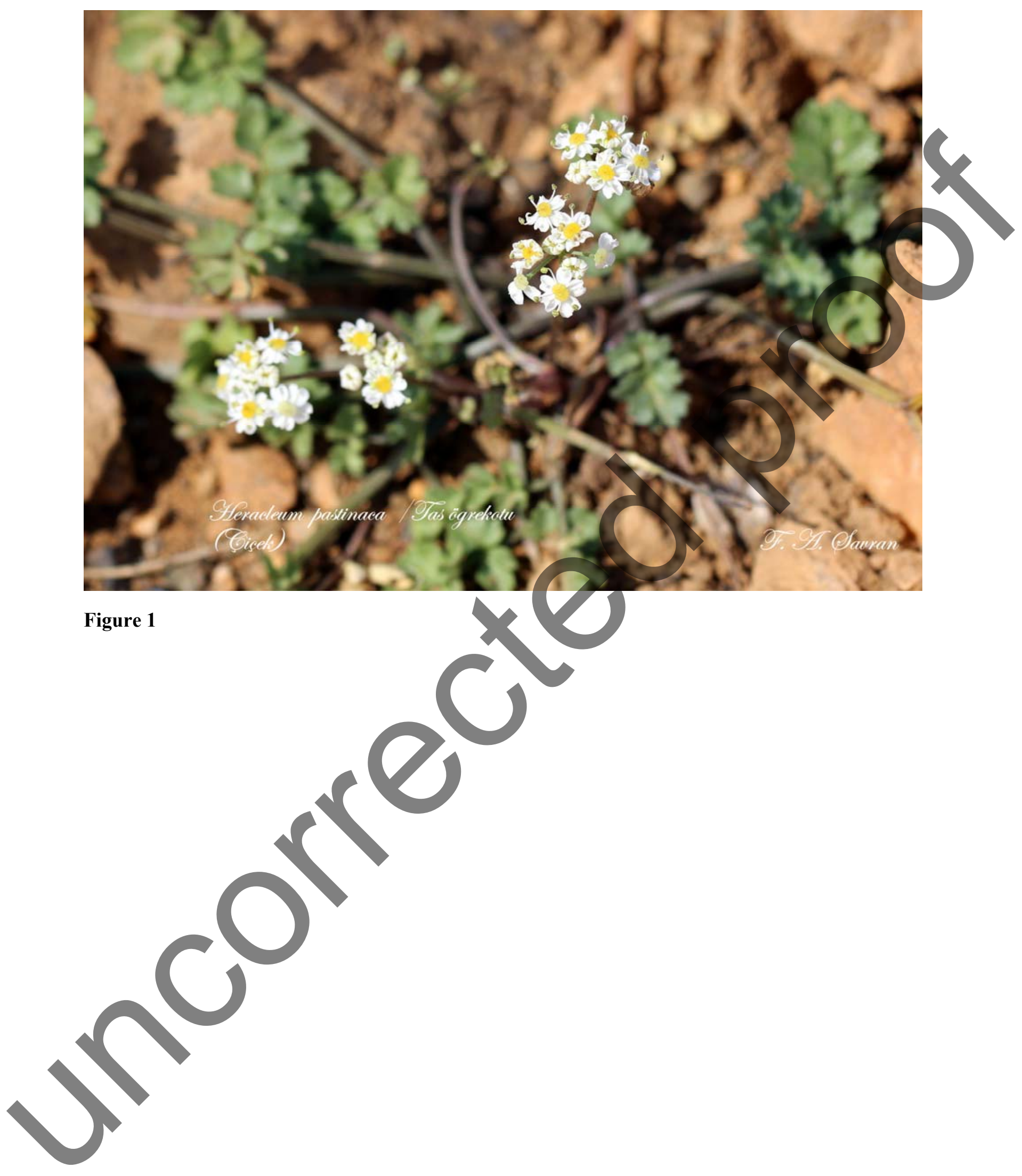



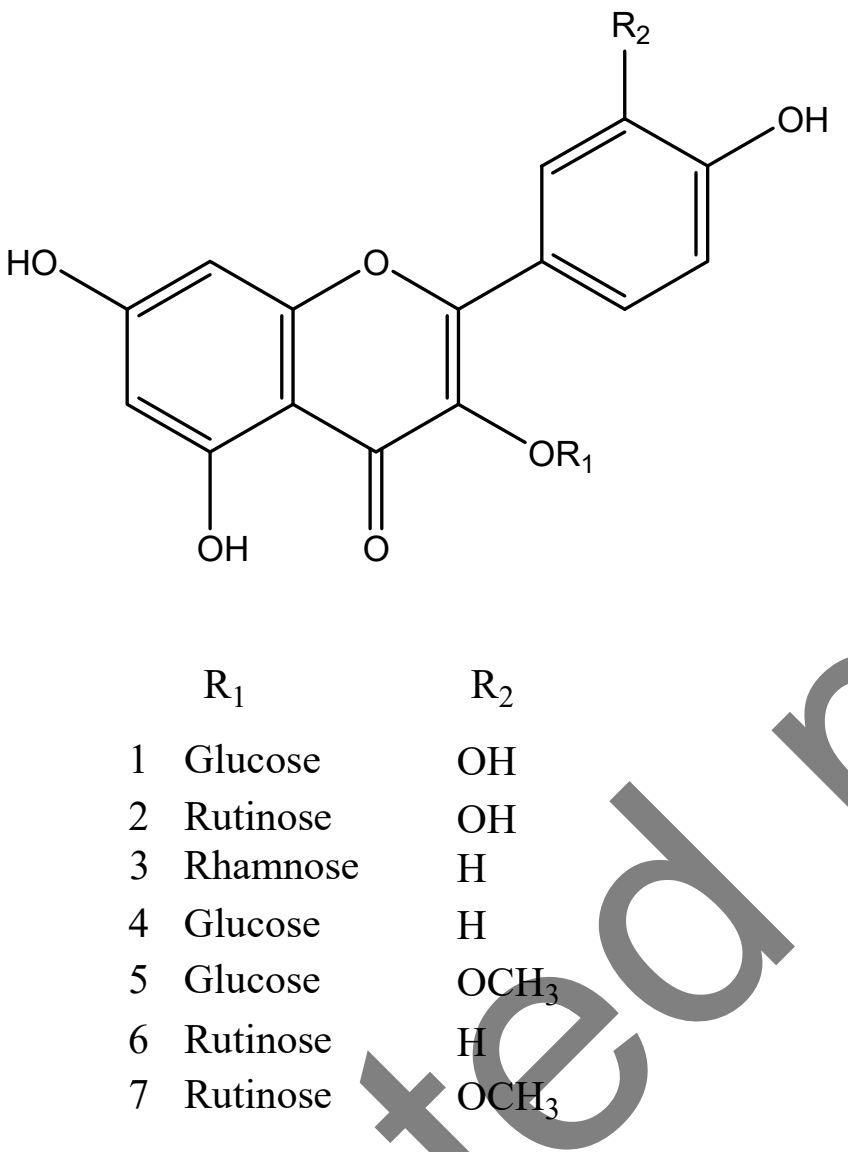

Figure 2. Isolated flavonoids from $H$. pastinaca 